
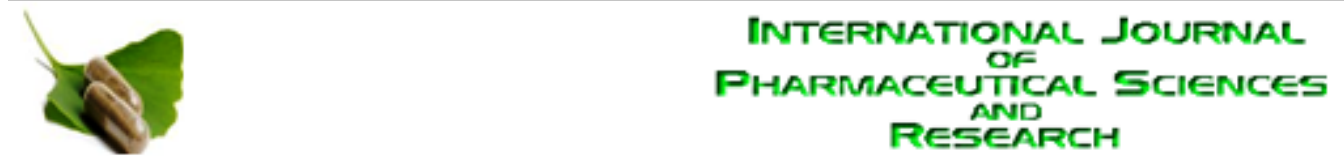

Received on 14 August, 2011; received in revised form 16 April, 2012; accepted 29 May, 2012

\title{
STUDY OF ANTITUSSIVE POTENTIAL OF GLYCYRRHIZA GLABRA AND ADHATODA VASICA USING A COUGH MODEL INDUCED BY SULPHUR DIOXIDE GAS IN MICE
}

Yasmeen Jahan* and H.H. Siddiqui

Faculty of Pharmacy, Integral University, Kursi Road, Lucknow, Uttar Pradesh, India

\section{ABSTRACT}

Keywords:

Antitussive activity,

Glycyrrhiza glabra,

Adhatoda vasica,

Codeine sulphate

Correspondence to Author:

Yasmeen Jahan

Faculty of Pharmacy, Integral University, Kursi Road, Lucknow, Uttar Pradesh, India
Cough is the most common symptom of respiratory diseases. When cough becomes serious, opioids are effective, but they have side effects like sedation, constipation. Therefore, there is a need to have effective antitussive agent which do not have respiratory depressant activity. The present study was carried out to evaluate antitussive activity of Glycyrrhiza glabra and Adhatoda vasica using a cough model induced by sulphur dioxide gas in mice. The effect of the ethanol extracts of Glycyrrhiza glabra and Adhatoda vasica on $\mathrm{SO}_{2}$ gas induced cough in experimental animals have very significant effects at the level of $p<0.01$ in inhibiting the cough reflex at a dose of $800 \mathrm{mg} / \mathrm{kg}$ and $200 \mathrm{mg} / \mathrm{kg}$ body wt. p.o., in comparison with the control group. Mice showed an inhibition of $35.62 \%$, in cough on treatment with Glycyrrhiza glabra and $43.02 \%$ inhibition on treatment with Adhatoda vasica within $60 \mathrm{~min}$ of the experiment. The antitussive activity of the extract was comparable to that of codeine sulphate $(10,15,20 \mathrm{mg} / \mathrm{kg}$ body wt.), a standard anti-tussive agent. Codeine sulphate, as a standard drug for suppression of cough, produced $24.80 \%, 32.98 \%$, and $45.73 \%$ inhibition in cough at a dose of $10 \mathrm{mg} / \mathrm{kg}, 15 \mathrm{mg} / \mathrm{kg}$ and $20 \mathrm{mg} / \mathrm{kg}$ respectively, whereas, codeine sulphate $(20 \mathrm{mg} / \mathrm{kg})$ showed maximum $45.73 \%(p<0.001)$ inhibition at $60 \mathrm{~min}$ of the experiment.
INTRODUCTION: A cough (Latin: tussis) is a sudden and forceful expiration of air from the lungs caused by an involuntary contraction of the muscles controlling the process of breathing. It is a protective reflex that removes foreign material and secretions from the bronchi and bronchioles. The cough reflex consists of three phases: an inhalation, a forced exhalation against a closed glottis 1. Ayurveda (Ayur-life, Vedaknowledge), is the knowledge of healthy living and is not merely confined to the treatment of illness. Ayurvedic medicines are largely based on herbal and herbo-mineral preparations and have specific diagnostic and therapeutic principles ${ }^{2}$.
Glycyrrhiza glabra is one of the most commonly used medicine in Indian indigenous system of medicine.

It is used as an energy tonic, particularly for the spleen and stomach, and the root is added to many formulae. It is also used for asthmatic coughs, as an antispasmodic and ulcer remedy, and to cool 'hot' conditions.

Roots of Glycyrrhiza glabra being tonic, demulcent laxative emollient are used in genito-urinary diseases, coughs and sore throat ${ }^{3}$. The antitussive activity of glycyrrhetinic acid and its derivatives has been evaluated ${ }^{4}$. 
Adhatoda vasica (AV) is an Ayurvedic medicinal plant which is a home remedy for several diseases. It is mentioned in Vedas as an herbal remedy for treating cold, cough, whooping cough and chronic bronchitis and asthma, as sedative expectorant, antispasmodic and anthelmintic. It is an official drug and is mentioned in the Pharmacopoeia of India (1966). The drug is employed in different forms such as fresh juice, decoction, infusion and powder; also given as alcoholic extract and liquid extract or syrup. The leaf juice is stated to cure diarrhoea, dysentery and glandular tumor and the plant is an emmenagogue.

The powder is reported to be used as poultice on rheumatic joints as counter-irritant on inflammatory swelling, on fresh wounds, urticaria and in neuralgia have shown that AV consists of peganine-type alkaloids namely vasicinone, vasicine and vasicinol ${ }^{6}$. Vasicinone and vasicinol have elicited bronchodialating action which is attributed to the quinazol-4-one ring system. Vasicine, on the other hand has elicited bronchoconstricting action. The active alkaloid vasicine and its auto oxidation product vasicinone have shown antitussive activity ${ }^{7}$.

The extract of leaves is traditionally used for the treatment of bronchitis. It is known to Ayurveda for 2000 years. The primary action of currently available cough suppressants on the central cough pathway. The significant side effects of these agents such as constipation, respiratory depression, dependence, drowsiness and death from this action limit their use in human and thus highly unsatisfactory ${ }^{8}$. So, the need of hour is to screen a number of medicinal plants for promising biological activity.

\section{MATERIALS AND METHODS:}

Plant Material: The dried part of plants was purchased from the local shop in the city (Lucknow) during the month of January 2011. Samples of plant material were given to National Botanical Research Institute (NBRI) Lucknow, India for identification and Taxonomic authentification. The test report from NBRI, Lucknow confirmed the authenticity of plant sample. Ref.No.NBRI/CIF/215/2011, Lucknow.

Extraction of Glycyrrhiza glabra: The roots and rhizomes (250 gm) was crushed and pulverized by mechanical grinder to make a coarse powder and extracted with ethanol (70\%v/v) using Soxhlet's extractor for $24 \mathrm{~h}$. The extract was concentrated under reduced pressure and then dried in air (yield $-35 \mathrm{~g}$ ). The extract stored in a refrigerator and reconstituted in distilled water before use. The yield of Glycyrrhiza glabra in $70 \%$ ethanol was $14 \% \mathrm{w} / \mathrm{w}$ with respect to the dry starting material.

Extraction of Adhatoda vasica: Leaves were crushed to a coarse powder and dried plant material ( $1 \mathrm{~kg}$ ) was extracted with $80 \%$ ethanol at room temperature. The alcoholic extract was dried at $40^{\circ} \mathrm{C}$ for 1 week and was maintained in the dark in a cool and dry place. AV extract was freshly dissolved or suspended in distilled water for oral administration. The yield of Adhatoda vasica in $80 \%$ ethanol was $0.4 \% \mathrm{w} / \mathrm{w}$ with respect to the dry starting material.

Experimental Animals used: The experiments were carried out in Albino mice of either sex weighing between 20-30 g obtained from animal house of Integral University. Animals were kept in the animal house at $26 \pm 2{ }^{\circ} \mathrm{C}$ in polyacrylic cages with not more than six animals per cage and maintained under standard laboratory conditions with Standard food and water ad libitum.

The animals were used for the experiment after an acclimatization period of one week before experimental sessions. Animals were divided into six groups, containing 6 mice each. The animal experiment was performed according to the university's ethical committee approval and guidelines R.No: IU/Pharm/M.Pharm/CPCSEA/10/30.

\section{Evaluation of Antitussive Activity:}

Sulphur dioxide $\left(\mathrm{SO}_{2}\right)$ induced Cough: Anti-tussive effect against sulphur dioxide $\left(\mathrm{SO}_{2}\right)$-induced cough was evaluated by the method as described by Miyagoshi, 1986 with slight modification ${ }^{9}$.

A vial containing $2 \mathrm{ml}$ of $500 \mathrm{mg} / \mathrm{ml}$ solution of sodium hydrogen sulfite (NaHSO3; Qualigens fine chemicals) in double distilled water was placed at the base of a dessicator and covered with a porcelain porous plate to serve as a platform for placement of mice as shown in Figure 1. 


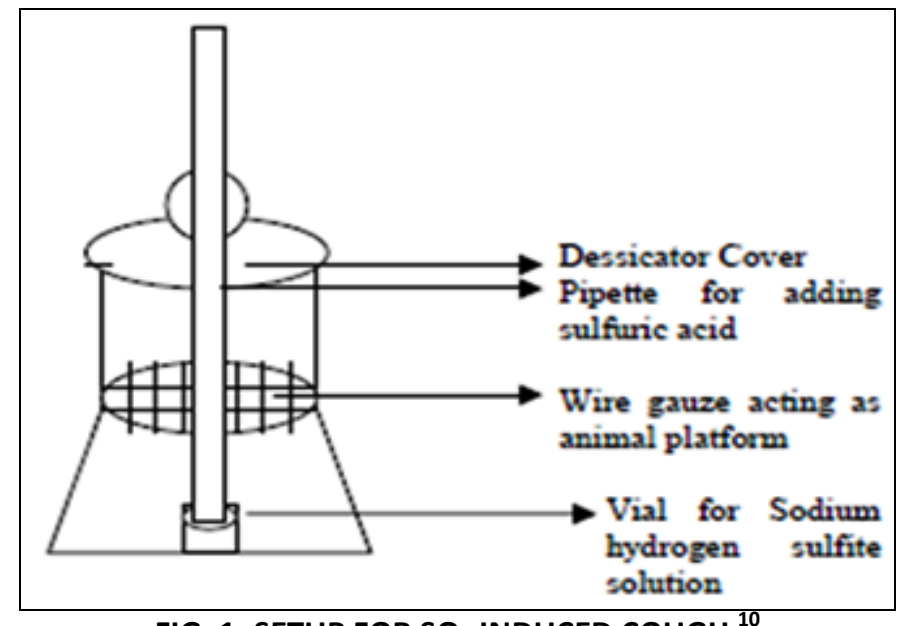

FIG. 1: SETUP FOR $\mathrm{SO}_{2}$ INDUCED COUGH ${ }^{10}$

To the $\mathrm{NaHSO}_{3}$ solution, $0.2 \mathrm{ml}$ of sulphuric acid $\left(\mathrm{H}_{2} \mathrm{SO} 4\right.$; Qualigens fine chemicals) was added using a pipette.

The reaction involved is as follows:

$$
2 \mathrm{NaHSO}_{3}+\mathrm{H}_{2} \mathrm{SO}_{4} \rightarrow 2 \mathrm{SO}_{2}+\mathrm{Na}_{2} \mathrm{SO}_{4}+\mathrm{H}_{2} \mathrm{O}
$$

After 15 seconds, the mice were placed on the platform in the desiccator and exposed to $\mathrm{SO}_{2}$ for 20 seconds. The mice were then removed from the desiccator and placed in an observation chamber for counting of bouts of cough for five minutes thereafter.

Initially the cough responses of all groups of animals were observed $(0 \mathrm{~min})$ by placing the animal individually in the desiccator and certain amount of $\mathrm{SO} 2$ gas $(5 \mathrm{ml}$, which was fixed throughout the experiment) was introduced. After 20 seconds exposure of the gas, the animal was taken out of the desiccator and the frequency of cough was observed for $5 \mathrm{~min}$ in an unended filter funnel. In this fashion the frequency of cough were observed for all the animal groups at 0 min before the drug administration and at $60 \mathrm{~min}$ after the drug administration.

Scoring of Bouts of Cough: In this fashion, the frequency of cough were observed for all the animal groups at $0 \mathrm{~min}$, before administration of any chemical or testing material. Since, it has been illustrated that cough response to a given stimulus varies from animal to animal but that repeated assessments within the same animals are fairly reproducible. Thus, animals having low or high cough threshold were not entertained for further studies. Number of coughs was observed for all animal groups at $60 \mathrm{~min}$ after drug administration by using same procedure.

Drug Treatment: All drugs were administered orally (p.o.). Animals were divided into six groups, containing 6 mice each. Treatment to be given to the animals are shown in Table 1. Group I served as control group and was not administered anything. Group II, Group III and Group IV was received standard drug ie. Codeine sulphate $10 \mathrm{mg} / \mathrm{kg}, 15 \mathrm{mg} / \mathrm{kg} \& 20 \mathrm{mg} / \mathrm{kg}$ p.o. respectively. Group $\mathrm{V}$ received ethanol extract of Glycyrrhiza glabra in dose of $800 \mathrm{mg} / \mathrm{kg}$ \& Group VI received ethanol extract of Adhatoda vasica in dose of $200 \mathrm{mg} / \mathrm{kg}$.

\section{TABLE 1: TREATMENT TO BE GIVEN TO THE ANIMALS}

\begin{tabular}{|c|c|c|}
\hline Groups & $\begin{array}{l}\text { Number of } \\
\text { Animals }\end{array}$ & Treatment to be given \\
\hline 1 & 6 & Normal Control \\
\hline II & 6 & $\begin{array}{l}\text { Treated with Standard drug codeine sulphate } \\
\qquad(10 \mathrm{mg} / \mathrm{kg}, \mathrm{p} . \mathrm{o})\end{array}$ \\
\hline III & 6 & $\begin{array}{l}\text { Treated with Standard drug codeine sulphate } \\
\qquad(15 \mathrm{mg} / \mathrm{kg}, \mathrm{p} . \mathrm{o})\end{array}$ \\
\hline IV & 6 & $\begin{array}{l}\text { Treated with Standard drug codeine sulphate } \\
\qquad(20 \mathrm{mg} / \mathrm{kg}, \mathrm{p} . \mathrm{o})\end{array}$ \\
\hline V & 6 & $\begin{array}{l}\text { Treated with test drug Glycyrrhiza glabra } \\
\qquad(800 \mathrm{mg} / \mathrm{kg}, \mathrm{p.o})\end{array}$ \\
\hline VI & 6 & $\begin{array}{l}\text { Treated with test drug Adhatoda vasica } \\
\qquad(200 \mathrm{mg} / \mathrm{kg}, \text { p.o) }\end{array}$ \\
\hline
\end{tabular}

Each animal served as its own control and was exposed to sulphur dioxide gas twice ie.before and 60 minutes after the drug treatment.

Statistical Analysis: Mean of cough bouts recorded was taken and percent inhibition in number of cough bouts calculated.The experimental results have been expressed as the mean \pm SEM. Significance was evaluated by the Student' $s$ ' $t$ '-test and $p$-value less than 0.05 vs control imply significance. ${ }^{11}$

\section{RESULTS \& DISCUSSION:}

Standardization of Cough Induction Model: Gupta, 2009 evaluated antitussive activity of formulations by using method of Miyagoshi, 1986 with slight modification ${ }^{9,10}$. He stated that a vial containing $2 \mathrm{ml}$ of $500 \mathrm{mg} / \mathrm{ml}$ solution of sodium hydrogen sulfite in double distilled water was placed at the base of a dessicator and covered with a wire gauze to serve as a platform for placement of mice. To the $\mathrm{NaHSO}_{3}$ solution, $0.2 \mathrm{ml}$ of sulphuric acid was added using a pipette. After 15 seconds, the mice were placed on the platform in the dessicator and exposed to $\mathrm{SO}_{2}$ for $45 \mathrm{~s}$. 
The mice were then removed from the dessicator and placed in an observation chamber for counting of bouts of cough for five minutes thereafter. But in laboratory condition, when the mice were placed on the platform, in the dessicator and exposed to $\mathrm{SO}_{2}$ for $45 \mathrm{~s}$ and then removed from the dessicator and placed in an observation chamber for counting of bouts of cough for five minutes thereafter, it produced too much cough, even on exposing for $50 \mathrm{sec}$ to $\mathrm{SO}_{2}$ gas caused death.

So, there was a need to standardize the method according to the laboratory condition. Concentration of sulphuric acid and sodium bisulphite was $0.2 \mathrm{ml}$ and $2 \mathrm{ml}$ respectively used through all the experiment. Although in the present study, the quantification of $\mathrm{SO}_{2}$ generated has not been attempted, it is expected that the quantity and saturation level in the chamber would be the same in all the exposures, as the other conditions were kept the same.

For the standardization of cough induction model according to the laboratory condition, the mice were exposed to $\mathrm{SO}_{2}$ in different time durations like 5 second to 50 second and cough was counted respectively. The effects exhibited by exposing the animals in different time durations have been presented in Table 2. The graphical representation of effects exhibited by exposing the animals in different time durations have been shown in Figure 2.
TABLE 2: STANDARDIZATION OF COUGH INDUCTION MODEL IN LABORATORY CONDITION

\begin{tabular}{ccc}
\hline $\begin{array}{c}\text { Weight of animals } \\
\text { (gm) }\end{array}$ & $\begin{array}{c}\text { Exposure of } \mathbf{S O}_{\mathbf{2}} \text { gas } \\
\text { (sec) }\end{array}$ & $\begin{array}{c}\text { Frequency of cough bouts } \\
\text { (In 5 min) }\end{array}$ \\
\hline 26 & 5 & - \\
22 & 10 & 4 \\
29 & 15 & 27 \\
23 & 20 & 79 \\
25 & 25 & 121 \\
26 & 30 & 173 \\
26 & 35 & 153 \\
24 & 40 & 309 \\
27 & 45 & 388 \\
28 & 50 & death \\
\hline
\end{tabular}

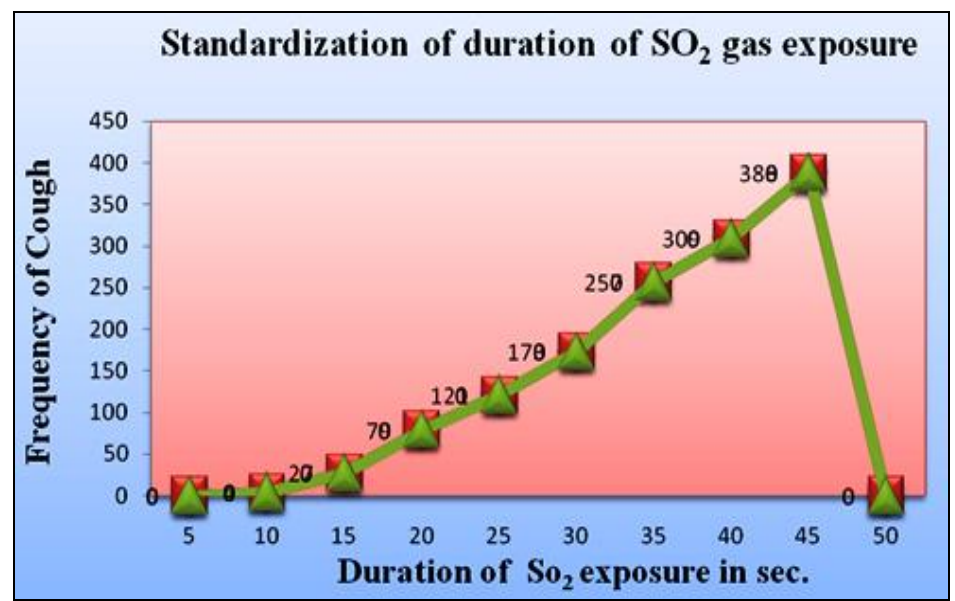

FIG. 2: STANDARDIZATION OF COUGH INDUCTION MODEL IN LABORATORY CONDITION

The effect exhibited by the entire treated group on sulphur-dioxide induced cough in experimental animals has been presented in Table $\mathbf{3}$.

TABLE 3: THE EFFECT EXHIBITED BY THE ENTIRE TREATED GROUP ON SULPHUR DIOXIDE INDUCED COUGH IN EXPERIMENTAL ANIMALS

\begin{tabular}{|c|c|c|c|c|}
\hline \multicolumn{5}{|c|}{ Effect of drugs on the cough reflex induced by $\mathrm{SO}_{2}$ gas in mice } \\
\hline Treatment & Dose (mg/kg) & No. of Animals & Frequency of cough (mean \pm SEM) & Inhibition (\%) \\
\hline \multirow[t]{2}{*}{ Control group } & -- & 6 & $85.66 \pm 5.31$ & -- \\
\hline & 10 & 6 & $64.50 \pm 6.45 *$ & $24.80 \%$ \\
\hline \multirow[t]{2}{*}{ Codeine sulphate } & 15 & 6 & $58.33 \pm 6.96 *$ & $32.98 \%$ \\
\hline & 20 & 6 & $47.00 \pm 7.72 * *$ & $45.73 \%$ \\
\hline Ethanol extract of Glycyrrhiza glabra & 800 & 6 & $56.16 \pm 7.76 * \#$ & $35.62 \%$ \\
\hline Ethonal extract of Adhatoda vasica & 200 & 6 & $50.50 \pm 9.81 * \#$ & $43.02 \%$ \\
\hline
\end{tabular}

In normal controls, there was no significant change in the number of cough bouts, between the two exposures. The effect of the ethanol extracts of Glycyrrhiza glabra and Adhatoda vasica on $\mathrm{SO}_{2}$ gas induced cough in experimental animals has significant effects at the level of $p<0.01$ in inhibiting the cough reflex at a dose of $800 \mathrm{mg} / \mathrm{kg}$ and $200 \mathrm{mg} / \mathrm{kg}$ body wt. p.o., in comparison with the control group.
Mice showed a inhibition of $35.62 \%$, in cough on treatment with Glycyrrhiza glabra and $43.02 \%$ inhibition on treatment with Adhatoda vasica. Codeine sulphate used as a standard drug for suppression of cough, produced $24.80 \%, 32.98 \%$, and $45.73 \%$ inhibition in cough at a dose of $10 \mathrm{mg} / \mathrm{kg}, 15 \mathrm{mg} / \mathrm{kg}$ and $20 \mathrm{mg} / \mathrm{kg}$ respectively. Whereas, codeine sulphate (20 $\mathrm{mg} / \mathrm{kg}$ ) showed maximum 45.73\% $\quad(p<0.001)$ inhibition at $60 \mathrm{~min}$ of the experiment. 
And the effect of the ethanol extracts of Glycyrrhiza glabra and Adhatoda vasica on $\mathrm{SO}_{2}$ gas induced cough in experimental animals also have significant $(p<0.05)$ effects in inhibiting the cough reflex at a dose of 800 $\mathrm{mg} / \mathrm{kg}$ and $200 \mathrm{mg} / \mathrm{kg}$ body wt. p.o., in comparison with the Standard group.

The frequency of cough was counted for 5 min after the sulphur dioxide gas challenge each sample was dissolved in $0.3 \mathrm{ml}$ distilled water. Statistical differences between plant extracts, standard (codeine) with baseline values; Significance was evaluated by Student's t-test ( $\mathrm{n}=6$ animals/experiment). ( $\left.{ }^{* *}\right)-\mathrm{P}<$ 0.01 as compared with control. $\left({ }^{* * *}\right)-\mathrm{P}<0.001$ as compared with control. $\left({ }^{\#}\right)-P<0.05$ as compared with codeine sulphate.

The graphical representation of results are shown in Figure 3, Figure 4, Figure 5, Figure 6.

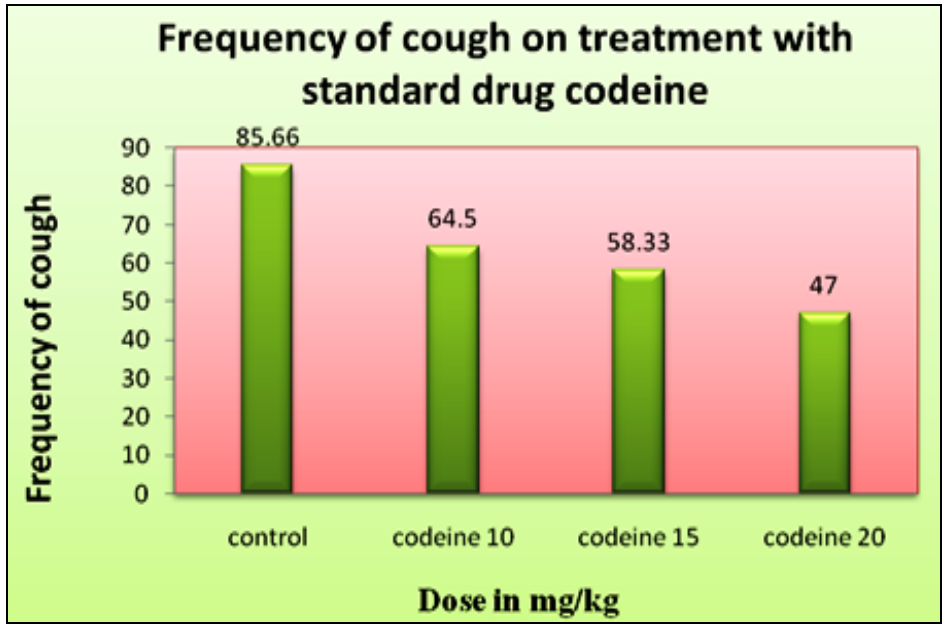

FIG. 3 : FREQUENCY OF COUGH ON TREATMENT WITH CODEINE

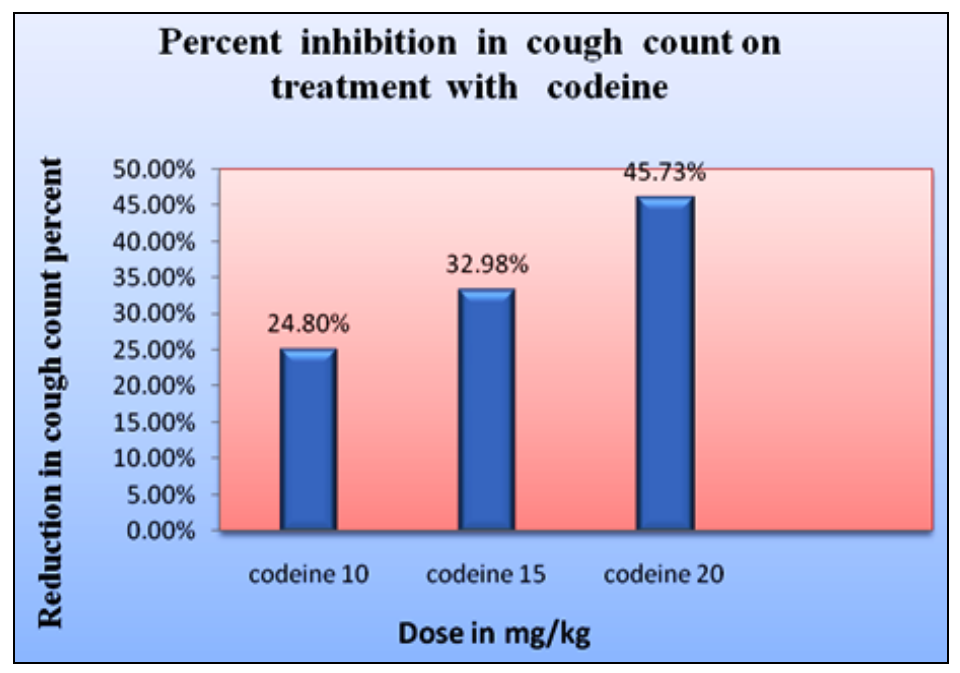

FIG 4: PERCENT INHIBITIONS IN COUGH ON TREATMENT WITH CODEINE

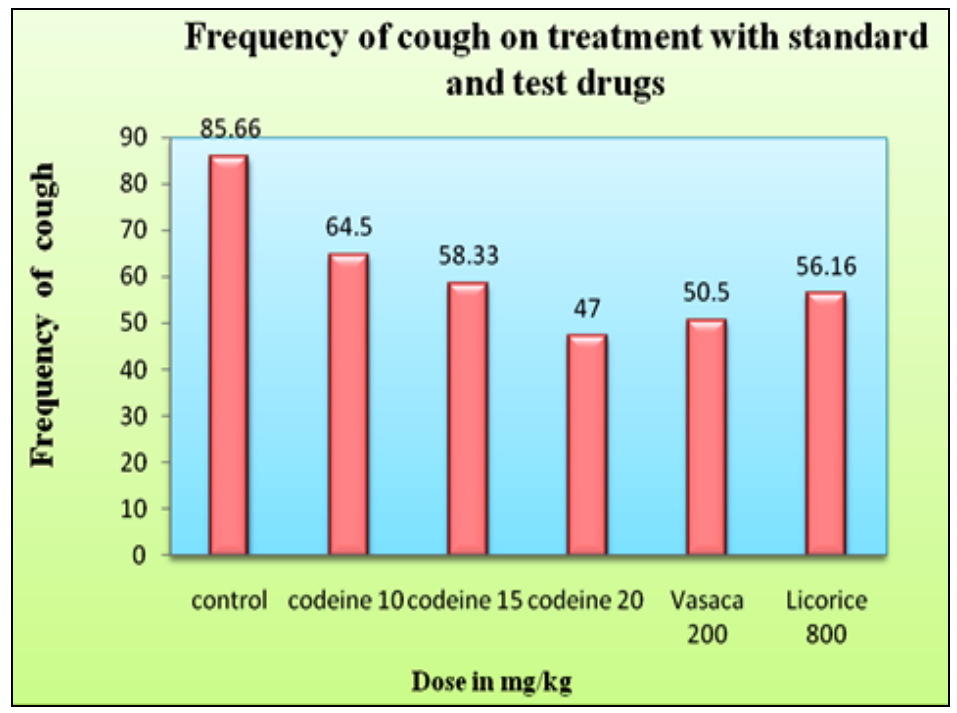

FIG. 5:

FREQUENCY OF COUGH ON TREATMENT WITH ALL DRUGS

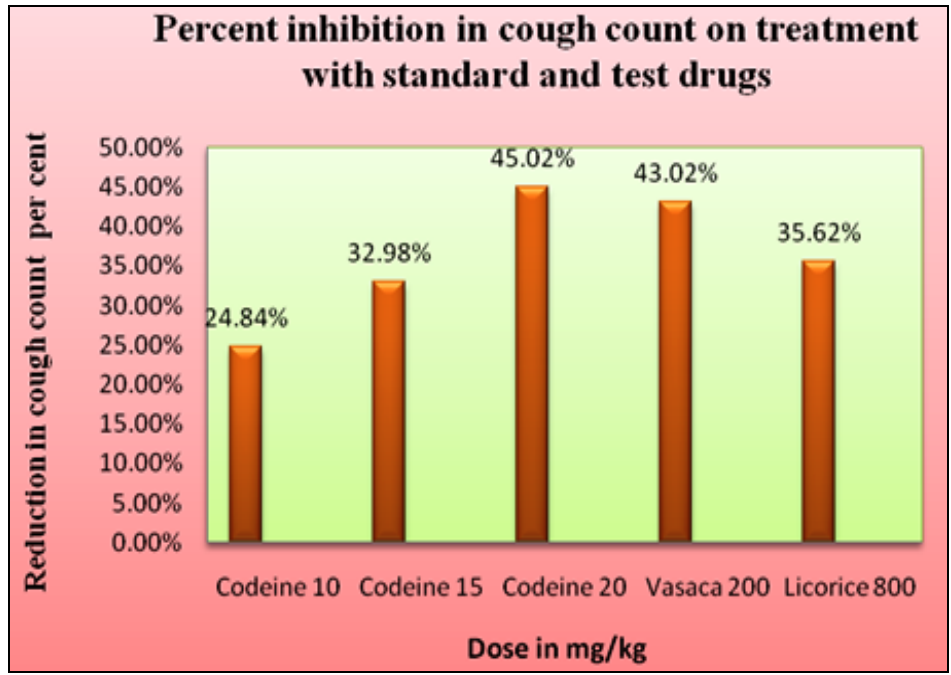

FIG. 6: COMPARATIVE STUDY OF PERCENT INHIBITION ON COUGH ON TREATMENT WITH ALL DRUGS

Herbs have been important contributors to the quality of human life for thousands of years. It has been estimated by World Health Organization (WHO) that approximately $80 \%$ of world's inhabitants, mainly residing in developing countries, rely on traditional medicine, and $85 \%$ of traditional medicine involves the use of plant extracts or their active principles ${ }^{12}$.

Many medicinal plants have been claimed to have antitussive activity. For example - Ocimum sanctum ${ }^{15}$, Ionidium suffruticosam ${ }^{16}$, Trichodesma indicum ${ }^{17}$, Abies webbiana ${ }^{18}$, Ficus racemosa ${ }^{19}$, Lagerstroemia parviflora ${ }^{20}$, Jussiaea suffruticosa ${ }^{21}$, Asparagus racemosus ,Solanum xanthocarpum ${ }^{22}$ etc. Ocimum sanctum(tulsi), ginger, Glycyrrhiza glabra (licorice/ mulethi), Voila odorata (banafsha), Justicia adhatoda (vasaka) leaves and Foeniculum vulgare (fennel)etc., 
are major components of household cough and cold remedies worldwide, in the form of decoctions, teas etc. Glycyrrhiza glabra is effective as an expectorant and demulcent in inflammation of bronchi tubules. The glycyrrhetic acid interferes with mucopolysaccharid synthesis. Adhatoda vasica increases bronchial secretion or reduce its viscosity, facilitating its removal by coughing.

Some isolated experimental and clinical studies have also been carried out on these agents for cough. Preliminary investigation shows promising results as antitussive and expectorant activity, this aspect has been further investigated so that these herbs can be established individually as a standard antitussive and expectorant drug. The model used in this study is a modification of Gupta, $2009^{10}$.

In the present study, the quantification of $\mathrm{SO}_{2}$ generated has not been attempted, it is expected that the quantity and saturation level in the chamber would be the same in all the exposures, as the other conditions were kept the same. The present data indicates that the ethanol extracts of both plant possesses obvious antitussive activity against chemically induced cough in mice. The antitussive activity of ethanol extracts of both the plant was tested and the results showed significant activity in this animal model which supports the use of the plant in traditional medicine. The ethanol extract at dose levels of $800 \mathrm{mg} / \mathrm{kg}$ (Glycyrrhiza glabra) and $200 \mathrm{mg} / \mathrm{kg}$ (Adhatoda vasica) showed significant activity after $1 \mathrm{~h}$ as far as the frequency of cough as well as inhibition of cough reflex is concerned.

It can be concluded that the ethanol extracts exerts a significant antitussive effect in experimentally induced cough reflex in mice comparable to the standard drug codeine sulphate. The cough supressant actualy of Glycyrrhiza glabra was $35.62 \%$ as compared to the actually of codeine sulphate. The cough supressant actualy of Adhatoda vasica was $43.02 \%$ as compared to the actually of codeine sulphate. The difference between test drugs (Glycyrrhiza glabra, Adhatoda vasica) and control group was very significant at the level of $p<0.01$. And the difference between test drugs (Glycyrrhiza glabra, Adhatoda vasica) and standard group (codeine sulphate) was significant at the level of $p<0.05$.
The result of the present study provides pharmacological evidence in support of the folklore-claim of Glycyrrhiza glabra and Adhatoda vasica as an antitussive agent.

ACKNOWLEDGEMENTS: The authors are thankful to Prof. S.W. Akhtar, Honourable Vice Chancellor, Integral University, Lucknow, for providing necessary facilities for the work.

\section{REFERENCES:}

1. Chung KF, Pavord ID, Prevalence, pathogenesis, and causes of chronic cough. Lancet 2008, 371(9621), 1364-74.

2. Patwardhan B. and Hooper M: Ayurveda and future drug development. Int. J. Alternative Complementary Med, 1992, 109-10.

3. Chopra RN, Nayar SL, and Chopra IC: Glossary of Indian Medicinal Plants. Indian Counsel of Scientific and Industrial Research, India, 1956.

4. Anderson DM, Smith WG. The antitussive activity of glycyrrhetinic acid and its derivatives. J Pharm Pharmacol 1961, 13,396-404.

5. Pharmacopoeia of India. Controller of Publications, Government of India, New Delhi, 2nd edition, 1966.

6. Amin, $\mathrm{AH}$, and Mehta BR, Bronchodialator alkaloid (vasicinone) from Adhatoda vasica. Nature 1959, 184-1317.

7. Dhuley JN, Antitussive effect of Adhatoda vasica extract on mechanical or chemical stimulation -induced coughing in animals. J Ethnopharmacol 1999, 67(3), 361-365

8. Rang, HP, Dale, MM, Ritter, JM, Flower, R.J, 'Pharmacology'. Churchill Livingstone publication, 1966.

9. Miyagoshi M, Amagaya S, Ogihara $Y$, Antitussive effects of Lephedrine, amygdalin, and makyokansekito (Chinese traditional medicine) using a cough model induced by sulfur dioxide gas in mice. Plant Med 1986, 4, 275-278.

10. Gupta YK, Jatinder Katyal, Gajendra Kumar, Jogender Mehla, CK. Katiyar, Naveen Sharma And Satpal Yadav, Evaluation of Antitussive Activity of Fomulation With Herbal Extracts in Sulphur Dioxide Induced Cough Model in Mice. Indian J Physiol Pharmacol, 2009, 53(1), 61-66.

11. Woodson RF. Statistical Methods for the Analysis of Biomedical Data. Wiley Series in Probability and Mathematical Statistics. Wiley: New York, 315-316.

12. Farnsworth NR, Akerele O, Bingel AS, Soejarto DD and Guo Z. Medicinal plants in therapy. Bull World Health Organ, 1985, 63,965-981.

13. Brevoort $\mathrm{P}$, The booming US botanical market. An overview. Herbalgram, 1998, 44, 33-46.

14. Tyler VE, Phytomedicines, back to the future. J Nat Prod, 1999, 62, 1589-1592.

15. Nadig Pd, Laxmi S, Study of antitussive activity of Ocimum sanctum Linn. in guinea pigs. Ind J Physiol Pharmacol, 2005, 49 (2), 243-245.

16. Boominathan R, Devi BP, Mandal S.C: Evaluation of antitussive potential of Ionidium suffruticosam Ging. (Violaceae) extract in albino mice. Phytother Res, 2003, 17(7), 838-839.

17. Srinath $K$, Murugesan $T$, Kumar Cha, Suba V, Das AK, Sinha $S$, Arunachalam G, Manikandanl, Effect of Trichodesma indicum extract on cough reflex induced by sulphur dioxide in mice. Phytomedicine, 2002, 9(1), 75-77. 
18. Nayak SS, Ghos AK, Srikanth K, Debnath B,Jha T, Antitussive activity of Abies webbiana Lindl. leaf extract against sulphur dioxide induced cough reflex in mice. Phytother Res, 2003, 17(8), 930-932.

19. Bhaskara Rao R, Murugesan T, Pal M, Saha Bp,Mandal S, Antitussive potential of methanol extract of stem bark of Ficus racemosa Linn. Phytother Res, 2003, 17(9), 1117-1118.

20. Mazumdar A, Saha BP, Basu SP, Mazumdar R, Boominathan R, Devi BP, Mandal SC, Evaluation of antitussive activity of
Lagerstroemia parviflora leaf extract. Phytother Res, 2004, 18(9), 780-782.

21. Murugesan, Ghosh, L, Mukherjee, PK., Pal, M, Saha, BP, Evaluation of antitussive potential of Jussiaea suffructicosalinn extract in Albino mice. Phytotherapy Research, 2000, 14, 541542.

22. Bector NP, Puri AS, Solanum xanthocarpum (Kantakari) in chronic bronchitis, bronchial asthma and non - specific unproductive cough. JAPI 1971, 19(10), 741-744. 